\title{
Potentialities in the performance of coating mortars through the addition of
} sewage sludge ash

\author{
Potencialidades no desempenho de argamassas de revestimento mediante a adição de cinzas de lodo
}

de esgoto

Potencialidad en el desempeño de morteros de revestimiento mediante la adición de cenizas de lodos de depuradora

\author{
João Victor da Cunha Oliveira \\ ORCID: https://orcid.org/0000-0003-1545-0082 \\ Universidade Federal de Campina Grande, Brasil \\ E-mail: joaovictorwo@gmail.com \\ Leila Soares Viegas Barreto Chagas \\ ORCID: https://orcid.org/0000-0001-5176-3866 \\ Instituto Federal do Sertão Pernambucano, Brasil \\ E-mail: leila.viegas@ifsertao-pe.edu.br \\ Frankslale Fabian Diniz de Andrade Meira \\ ORCID: https://orcid.org/0000-0002-0306-3221 \\ Instituto Federal da Paraíba, Brasil \\ E-mail: frankslale.meira@ifpb.edu.br \\ Arnaldo Manoel Pereira Carneiro \\ ORCID: https://orcid.org/0000-0002-4279-7156 \\ Universidade Federal de Pernambuco, Brasil \\ E-mail: ampc@ufpe.br
}

\begin{abstract}
Through environmental policies that provide a gradual discussion about the destination of the tailings produced in the most diverse industrial sectors, the sewage sludge is emphasized by the problematic destination arising from the amount of toxic compounds that compose it, compromising its disposal. Aiming to fulfill the sustainable role through the creation of mechanisms that favor the ecological coexistence between environment and human beings, it is possible through the use of construction materials, considered as conventional, the use of calcined sewage sludge as an enhancer of the properties of matrix materials cement, significantly improving its performance against mechanical stresses and degradation mechanisms. Based on the need to implement measures to mitigate environmental impacts through the production of eco-efficient materials, the ashes of sanitary sewage sludge as a partial substitute for Portland cement have now been used as an input in coating mortars. This substitution focuses on reducing the large volume of sludge generated by the Sewage Treatment Plants, as well as on the reduction in the consumption of cement, a large $\mathrm{CO}_{2}$ generator during its manufacturing process. It was observed that through the use of this calcined by-product applied in mortars, a relevant physical-mechanical performance in cementitious materials is ratified, that in comparison to the material without the use of it, better results are observed, resulting from the reactivity conferred to the sludge after the thermal degradation process, making it a pozzolana.
\end{abstract}

Keywords: Calcined sewage sludge; Coating mortars; Feasibility of use; Mechanical behavior; Pozzolana.

\section{Resumo}

Através das políticas ambientais que proporcionam uma paulatina discussão a respeito da destinação dos rejeitos produzidos nos mais diversos setores industriais, o lodo de esgoto é posto em ênfase pela problemática destinação advinda da quantidade de compostos tóxicos que o compõe, comprometendo o seu descarte. Objetivando cumprir o papel sustentável mediante a criação de mecanismos que favoreçam a convivência ecológica entre meio ambiente e seres humanos, viabiliza-se através dos materiais de construção, tidos como convencionais, o uso do lodo de esgoto calcinado como potencializador das propriedades de matérias de matriz cimentícia, melhorando significativamente o seu desempenho frente aos esforços mecânicos e mecanismos de degradação. A partir da necessidade de implantar medidas mitigadoras dos impactos ambientais através da produção de materiais ecoeficientes, passou-se a utilizar atualmente como insumo, em experimentos com argamassas de revestimento, as cinzas do lodo de esgoto sanitário como substituto parcial do cimento Portland. Essa substituição possui enfoque na redução do grande volume de lodo gerado pelas Estações de Tratamento de Esgoto, como também na atenuação no consumo de cimento, um grande gerador de $\mathrm{CO}_{2}$ durante seu processo de fabricação. Pôde-se observar que por meio do uso desse subproduto calcinado aplicado em argamassas, ratifica-se uma relevante performance físico-mecânica em materiais cimentícios, que em 
comparação ao material sem o uso do mesmo, observam-se melhores resultados, advindos da reatividade conferida ao lodo posterior ao processo térmico de degradação, tornando-a uma pozolana.

Palavras-chave: Lodo de esgoto calcinado; Argamassas de revestimento; Viabilidade de uso; Comportamento mecânico; Pozolana.

\section{Resumen}

A través de políticas ambientales que brindan una discusión paulatina sobre el destino de los relaves producidos en los más diversos sectores industriales, los lodos de depuradora son enfatizados por el destino problemático derivado de la cantidad de compuestos tóxicos que lo componen, comprometiendo su disposición. Con el objetivo de cumplir con el rol sustentable mediante la creación de mecanismos que favorezcan la convivencia ecológica entre el medio ambiente y el ser humano, es posible mediante el uso de materiales de construcción, considerados como convencionales, el uso de lodos de depuradora calcinados como potenciador de las propiedades de la matriz. materiales cemento, mejorando significativamente su desempeño frente a tensiones mecánicas y mecanismos de degradación. Con base en la necesidad de implementar medidas para mitigar los impactos ambientales a través de la producción de materiales ecoeficientes, las cenizas de los lodos de depuradora sanitaria como sustituto parcial del cemento Portland se han utilizado ahora como insumo en los morteros de revestimiento. Esta sustitución se centra en la reducción del gran volumen de lodos que generan las Plantas de Tratamiento de Aguas Servidas, así como en la reducción del consumo de cemento, gran generador de $\mathrm{CO}_{2}$ durante su proceso de fabricación. Se observó que, mediante el uso de este subproducto calcinado aplicado en morteros, se ratifica un desempeño físico-mecánico relevante en materiales cementosos, que en comparación con el material sin el uso del mismo, se observan mejores resultados, producto de la reactividad conferido al lodo después del proceso de degradación térmica, convirtiéndolo en una puzolana.

Palabras clave: Lodos de depuradora calcinados; Morteros de revestimiento; Viabilidad de uso; Comportamiento mecánico; Puzolana.

\section{Introduction}

The accelerated population growth and the lack of infrastructure to accompany such growth, creates problems related to basic sanitation, because it causes an increase in the production of sludge in treatment plants.

In Brazil, already in the second half of the 20th century, factors such as the growth of cities and urban agglomerations with the increase in immigration flows, aggravated sanitation problems, with epidemics reproducing periodically (Passeto, 2006). This rapid inversion has caused the lack of sanitation to become one of the main environmental and public health problems in Brazil.

The Brazilian Ministry of the Environment estimates that about $10 \%$ of urban sewage is treated at Sewage Treatment Plants (STPs). This treatment results in the production of a sludge rich in organic matter and nutrients.

Sludge production can be considered as a sanitation problem, due to the population growth that increases its production, implying an increasing demand for area for its environmentally adequate final disposal. Planning the final disposal of sewage sludge from an STP requires technical and environmental knowledge and there are economic issues that guide the absence of this practice. According to Von Sperling, Gonçalves \& Luduvice (2001), the processing and final disposal of the sludge can represent up to $60 \%$ of the operating cost of an STP.

STPs have been looking for recycling solutions for the sludge generated in their treatment processes, because in some cities in Brazil the sludge generated is discarded in landfills, treatment plants (when they have one), and in some, it is only discarded due to problems related to the lack of basic sanitation that is in compliance with the environmental standards in force.

According to Guimarães, Cordeiro \& Vitorino (2018), the treatment of wastewater is essential to maintain environmental health and prevent the spread of diseases, however, during this process a by-product called sewage sludge is generated, whose final disposal has been become a major problem, since its volume increases as the number of people who have access to sanitation grows.

According to Waldemar (1992), in urban areas, sanitary sludge is generated daily in large volume, depending directly on the percentage of sewage that is treated. It is estimated that they can reach an amount in the order of $1000 \mathrm{~g} / \mathrm{inhabitant} / \mathrm{day}$, of partially dry material, which may contain between 70 and $90 \%$ of water in its composition. When totally dehydrated, it 
becomes, on average, 150g/inhabitant/day. When the calcination of the totally dehydrated sludge is carried out, approximately $33 \%$ of the dry material is obtained from ash (by mass) (Geyer, 2001).

The disposal of the most used sludge, until the 1960s, took place in landfills, however, with the growth of cities and the consequent increase in the amount of waste, this alternative became ineffective from the environmental point of view. In large cities, environmental legislation increasingly restricts the disposal of sludge in landfills, the major problem being the scarcity of suitable locations and the high costs for such disposal.

The final disposal of sewage sludge residue has been the subject of several studies, since it has become a serious environmental problem, because if on the one hand basic sanitation and public health are promoted through sewage treatment, on the other hand is generated in undesirable compound processes due to the high polluting load they carry.

A proposal to alleviate the problem regarding sewage sludge would, according to Cunha Oliveira, Chagas, Meira, Carneiro \& Melo Neto (2020), through its insertion in Portland cement mortar, where the use of cement would be reduced through the insertion of the calcined by-product, and when evaluating the performance and potential of adherence to the masonry substrate and flexion traction, which are some of the parameters of fundamental importance to ratify the final viability of the residue with large-scale application for masonry coatings, it was noted if it is possible to carry out such an application.

Data from the Sindicato Nacional da Indústria do Cimento - SNIC (2012), point out that in Brazil the consumption of cement exceeded the mark of 69 million tons. Linked to production and consumption, it is estimated that about $5 \%$ of all production of carbon dioxide, which is highly polluting, originates directly in the cement industry (Damtoft, Lukasik, Herfort, Sorrentino \& Gartner, 2008).

According to Giffoni \& Lange (2005), civil construction is the sector responsible for the consumption of the largest volume of natural resources, in estimates that vary between 15 and $50 \%$ of the extracted resources, in addition to their products being great consumers of energy, and for these reasons, the development of alternative materials that meet this activity is of fundamental importance.

In this way, any measure aimed at reducing the consumption of cement will be of great help to the environment, in order to reduce the possible impacts generated to it. In this context, research in several sectors is being developed seeking solutions that minimize design and environmental impacts and maximize the conservation of natural resources resulting from the use and production of materials and components used in the various stages of civil construction.

Therefore, the use of waste can be considered as a practice for sustainability in civil construction, being the use of sewage sludge ash from STP an alternative for the final destination of this waste that in the urban environment is constituted today in an environmental problem faced by sanitary engineering, as they are generated daily and in large volume.

The insertion of waste in executive construction processes is a way of minimizing the environmental impacts caused by the industry due to the use of so many natural resources, as according to Agopyan (2000), in the construction industry, the production of cement and concrete, due to the high volumes, it has been a major consumer of waste, fulfilling the role of neutralizing materials that, if left in nature, would be harmful.

In this context, a sector that has a huge potential to contribute to the minimization of environmental problems through the use of waste is the construction industry, since through the aforementioned literature, there are several solutions for it to incorporate waste in its stages and one of the possibilities of including sewage sludge is through its calcination so that it is used in coating mortars, replacing Portland cement.

The objective of this work is to present a systematic state of the art corresponding to the use of calcined sewage sludge applied in cementitious matrix materials (coating mortar), presenting practical results of how the use of this artificial pozzolan is beneficial both for the environment and for production of unconventional materials, and in addition, emphasize the adoption of sewage sludge as an input in the Portland cement manufacturing chain. 


\section{Methodology}

As a methodology, a bibliographic search was carried out in the main scientific databases (ScienceDirect, Google Scholar, and Scielo), about the types of ecological concrete developed in Brazil and in the world, and ways of applying this unconventional technology. Thus, the ideas advocated at the beginning of this study will be explained according to the types of concretes that have practical application potential, according to each study location, as well as before the respective solid residues that are adopted as renewable inputs in their compositions (Cunha Oliveira, 2020).

\section{Theory}

In view of the technological advances that the civil construction sector is immersed in, measures that can provide innovation, economy and less environmental impacts due to the vast and intense use of natural resources are being increasingly palatable.

The need for innovation in products and processes arising from construction activities due to the environmental impacts caused, is directly linked to studies related to the use of alternative materials, as efforts to reduce environmental impacts due to the use of natural resources, must be focused on the use of materials and components that provide the improvement of the quality of the works, in the reduction of energy consumption, in the reduction of the execution time of the activities related to the construction stages, in the reduction of costs, in the reduction of waste, as well as in sustainability making the project efficient.

There are three main reasons that motivate countries to recycle their industrial waste; first, the depletion of reserves of reliable raw materials; the growing volume of solid wastes, which endanger public health and degrade natural resources and, finally, the need to compensate for the imbalance caused by high oil prices (Menezes, Neves \& Ferreira, 2002).

Several scholars from developing countries analyze in their studies the insertion of waste in civil construction. Tay (1987), carried out studies and research aiming at the reuse of sewage sludge in the construction industry, aiming at inserting the waste for the production of ceramic blocks. Civil construction is an industry that has considerable potential for incorporating waste in its construction stages with the possibility of cost reduction and reduction of environmental damage, and in coating mortars such practice needs to be thoroughly evaluated and researched.

In addition to the practice that civil construction addresses with regard to the absorption of residues in cementitious materials, Geraldo (2016) proposed a model for creating a binder with properties similar to Portland cement, through alkaline activation, consisting of sludge from Water Treatment Plant and rice husk ash. The author replaced the metakaolin with sludge and rice husk ash, separately, during the binder activation process from sodium hydroxide $(\mathrm{NaOH})$ cured at room temperature. It was possible to obtain, after 28 days of hydration, a mortar with a resistance of $25 \mathrm{MPa}$ when the metakaolin was replaced in $15 \%$ by the sludge, a value within the acceptable parameters in the civil construction when mortars are involved. Another relevant parameter for the study was the fact that the material developed has low efflorescence, a pathology associated with the leaching of soluble compounds, which manifests itself on the surface of the material, physically deteriorating it and causing partial loss of its performance, and the applied sludge in the study brought a significant reduction in this item assessed.

Viana (2013), sought to apply the calcination method to extract the adsorbent potential that sewage sludge denotes when subjected to high temperatures. The burning consisted of submitting the dry material, macerated and sieved in ABNT mesh $\mathrm{n}^{\circ} 200$ to the thermal degradative process at $500^{\circ} \mathrm{C}$ for 5 different isotherms. The times of 30 and 60 minutes showed satisfactorily superior results compared to activated carbon for removing pollutants, such as phenol and tartrazine, from aqueous media.

Thus, it is observed that through the use of sewage sludge, in natura or calcined, several benefits can be obtained in the environmental and technological spheres. The products created in an attempt to resolve environmental impacts are 
characterized by the viability proven through laboratory tests, which characterize inorganically, the properties of the material created and the residue in its application form.

\subsection{Coating Mortar}

The coating mortar has different types, according to their function. The roughcast is the initial layer of preparation of the base, with the purpose of improving the adhesion of the other layers. The plastering is carried out over the roughcast layer and its purpose is to regularize the surface to receive the plaster (finish also in mortar to receive the paint) or for the adhesive mortar when the finish is in ceramic pieces.

According to Recena (2012), mortars should be considered as an element of a system and not in isolation as a material. Still according to the author, the coating mortars must have characteristics that allow a good finish, absorption of the natural deformations that the structure is subject to, waterproofing of the substrate, among others (Recena, 2012). The study on the pozzolanic activity index, which evaluates the calcined sewage sludge using mortars, partially replacing the cement, is of great importance to assess whether the unconventional material (calcined sludge) has similar characteristics to the binder (cement).

\subsection{Constituents of Portland Cement}

According to Mehta \& Monteiro (2008), one of the main primary constituents of Portland cement is the sources of calcium silicate. The discovery of pozzolanic activity in a given residue can direct its use in the manufacture of cements, where they are used to guarantee the binding properties of the material. The study of the aggregated alkali reaction in mortars using calcined sewage sludge is necessary to evaluate the durability of the mortar made using non-conventional material, in this case the calcined sewage sludge that will be partially incorporated in place of the cement.

According to Couto (2008), there are three main constraints for the aggregate alkali reactions to occur: the presence of an aggregate with reactive minerals, a high concentration of alkaline hydroxides $(\mathrm{NaOH}, \mathrm{KOH})$ in the pores of the concrete and, finally, the presence of sufficient moisture to expand the gel and form cracks in the concrete, in which the calcined sewage sludge shows potential in reducing the expansive process by the amorphous structure conferred to the pozzolan through the calcination process, which manifests itself when acting as a substitute for the Portland cement (Oliveira, 2017).

\subsection{Sustainability}

Law n. 12.305 (2010) clarifies the prevention and reduction of waste generation, with the proposal, the practice of sustainable consumption habits and a set of instruments to promote the increase of recycling and reuse of solid waste and the destination environmentally adequate disposal of waste, that is, that which cannot be recycled or reused. The Law is the basis of the Solid Waste National Policy, which, in terms of its guidelines, establishes the shared responsibility of waste generators, so that the final destination of each waste is environmentally appropriate.

Law n. 11.445 (2007) establishes the national guidelines for basic sanitation and for the federal basic sanitation policy; priority, in government procurement and contracting for recycled and recyclable products and goods, services and works that consider criteria compatible with socially and environmentally sustainable consumption patterns; integration of waste pickers of reusable and recyclable materials in actions involving shared responsibility for the life cycle of products; encouraging the implementation of the product life cycle assessment; incentive for the development of environmental and business management systems aimed at improving production processes and the reuse of solid waste, including energy recovery and utilization and encouraging environmental labeling and sustainable consumption.

According to Moura (2000), the concern with the serious problem of waste generation has been raising awareness in 
society of the need to carry out studies with a view to improving the production cycle and adjusting the destination of the waste generated.

Countless are the by-products from urban activities that have not yet been studied for use in the construction industry and that have a great potential for reuse/recycling, minimizing their discharges in nature, one of which is the sewage sludge generated in STPs, because the its application in agriculture is a practice used worldwide with abundant studies, but to make the use in the civil construction industry feasible, the studies need to be expanded.

The insertion of calcined sludge in the construction industry provides advantages such as: reducing the volume of waste in landfills, since its production is considered problematic due to the large amount of daily production; the reduction of the risk of contamination to the environment, since not all sludge produced is stored in environmental compliance; and the reduction in the use of Portland cement, which is considered to be one of the biggest polluters of the environment due to its manufacturing process that emits a large amount of $\mathrm{CO}_{2}$ in the air.

\section{Discussion}

The high energy consumption of industrialized materials favors the study of actions to plan the reuse of waste. Among urban waste, one of the most problematic is that generated in domestic sewage treatment processes, the so-called sludge from sanitary sewage treatment plants.

Andreoli, Ferreira, Bonnet, Lara \& Pegorini (1998), explain that the quantity and quality of the sludge produced by an STP depends on the flow of treated sewage, the characteristics of the sewage, the type of treatment and the operation of the STP, and must be taken taking into account that for each region of the country, there are several products generated through the chosen treatment process, which will vary in each reality.

Pedroza et al. (2010), state that, per year, the production of sludge ranges from 150 to 220 thousand tons of dry material, and that considering that only $30 \%$ of the population has its sewage properly collected and treated, it is assumed that in $100 \%$ of collection, the annual volume produced would exceed the mark of 400 thousand tons.

This large volume of sludge generating high operating costs demand from the sewage treatment plant itself in the disposal designation, and the consequent applicability of this by-product in construction materials is characterized as viable from the calcination process, eliminating organic matter and conferring reactivity to the ashes obtained, producing very important chemical reactions in obtaining crystalline phases due to the pozzolanic reactivity of the calcined material when in contact with the calcium hydroxide, a hydration product of Portland cement.

\subsection{Sludge Aggregates}

Brosch, Alvarinho \& Souza (1976), produced the first light aggregates using sewage sludge. The sewage sludge in this study was first used in the raw state and then crushed and dewatered from the STP in Pinheiros, in the city of São Paulo. The process used was sintering, which consisted of the following steps: sludge drying; pelletizing and transformation into light aggregates through sintering, where the agglomerates are calcined by self-combustion. The quality of these aggregates was considered satisfactory in terms of the abrasion resistance test and the mechanical resistance to crushing.

The production process of the light aggregate, from the sludge from the sewers, went through the following unit operations: sludge dehydration; post-drying of the centrifuged sludge; dosing and mixing of components; pelletizing; drying the pellets by fluidized bed; and sintering (Brosch, Alvarinho \& Souza, 1976).

The sewage sludge produced in the city of Londrina was used to produce light aggregate. From the studies carried out it was possible to conclude that the final product presented characteristics compatible with the requirements and criteria established by the Brazilian specifications regarding the production of concrete elements for masonry, production of structural 
concrete or for thermal insulation (Morales \& Agopyan, 1992).

The researchers from the Technological Research Institute (IPT), carried out an experimental research on the use of the digested sludge from STP in Pinheiros - São Paulo, and obtained a material that after crushing was classified within the specifications of light aggregate for use in industry of civil construction, with jobs in concrete structures, thermal insulation, filling of voids, prefabrication of buildings and blocks for masonry and floors. A semi-industrial facility, whose project was developed by Brazilian companies, was implemented at ERQ Leopoldina (Water Quality Recovery Station), with mechanical and electrical components manufactured in the country, and was in operation from June until the end of 1989 (Santos, 2003).

\subsection{Mechanical Properties}

Lessa (2005), evaluated some properties of mortars with insertion of calcined sewage sludge at $550^{\circ} \mathrm{C}$, for 3 different formulations $(1: 3,1: 4,5$ and 1:6), replacing cement in fixed percentages of 5\%,10\% and $20 \%$ to measure the compressive strengths after 28 days of mortar curing (Figure 1). The author observed that for all the formulations, all the sludge percentages added, favored the respective increase in resistance compared to the reference formulation (Figure 2), making it possible to effectively apply the ashes arising from the calcination process to replace the cement, agent generator of significant $\mathrm{CO}_{2}$ depositions in the atmosphere.
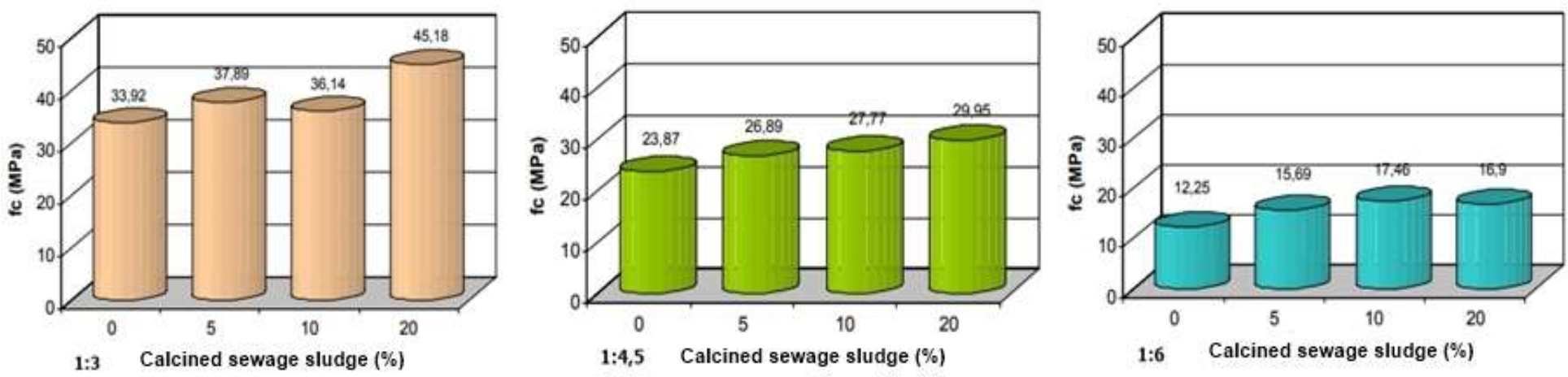

Figure 1 - Axial compression strengths of mortars with sewage sludge ash.

Source: Lessa (2005).

Figure 2 - Behavior of each formulation according to the amount of ash added.

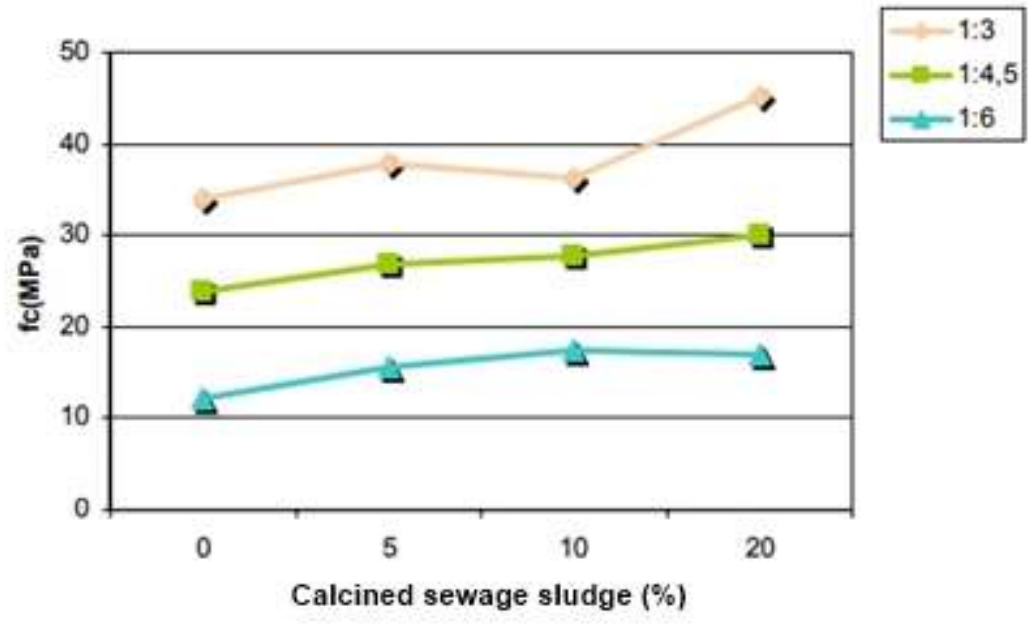

Source: Lessa (2005). 
Simoka, Reis \& Boni (2016), when evaluating the application of sewage sludge in mortars, concluded that, through physical tests for the hardened state of the material, such as the performance of axial compression and flexion traction, in up to $15 \%$ of use, there is no damage to the material, being able to incorporate the sludge calcined at $850^{\circ} \mathrm{C}$ in the mortars for 3 hours of isotherm (Figure 3).

Figure 3 - Physical-mechanical analysis of mortars with calcined sewage sludge.
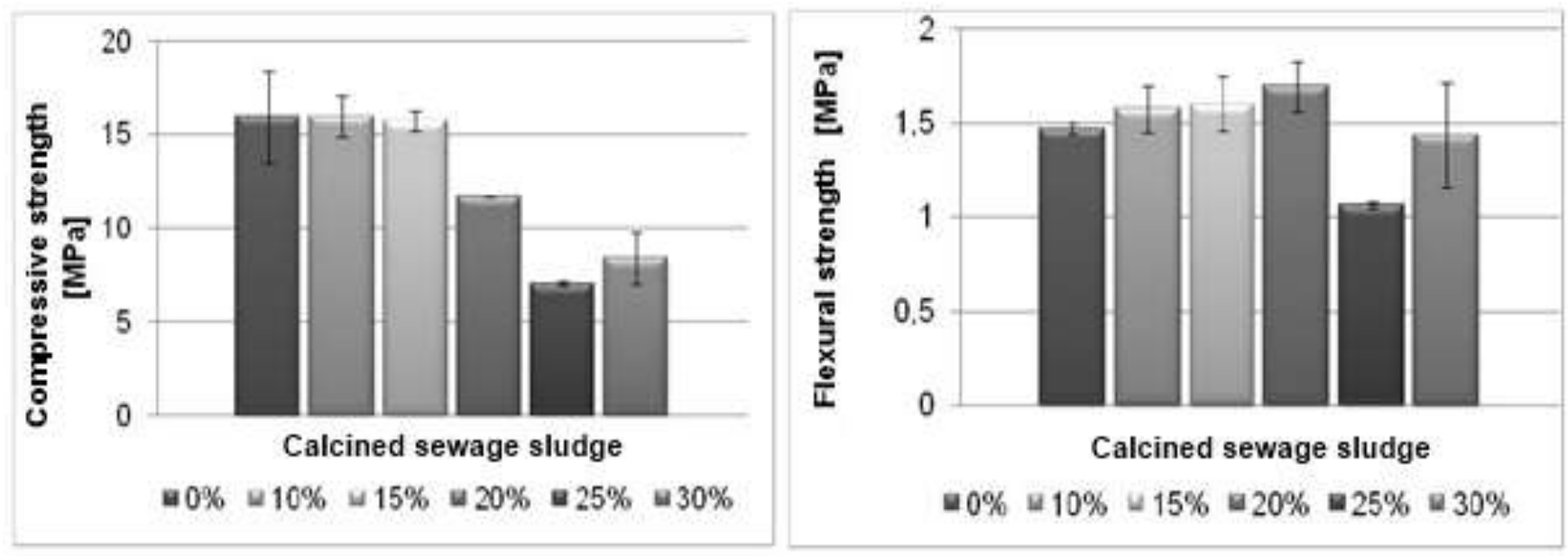

Source: Simoka, Reis \& Boni (2016).

Ingunza, Camarini \& Costa (2018), when incorporating the sewage sludge ash (SSA), calcined at a temperature of $850^{\circ} \mathrm{C}$ for 3 hours, in mortar as a mineral addition, realized that the percentage of $20 \%$ is ideal for application to from a conjunctural analysis of all the parameters analyzed, corroborating even more satisfactory results when comparing the mortar without adding the SSA for axial compression tests (Figures 4 and 5).

Figure 4 - Compressive strength of mortars at 28 and 91 days with SSA.

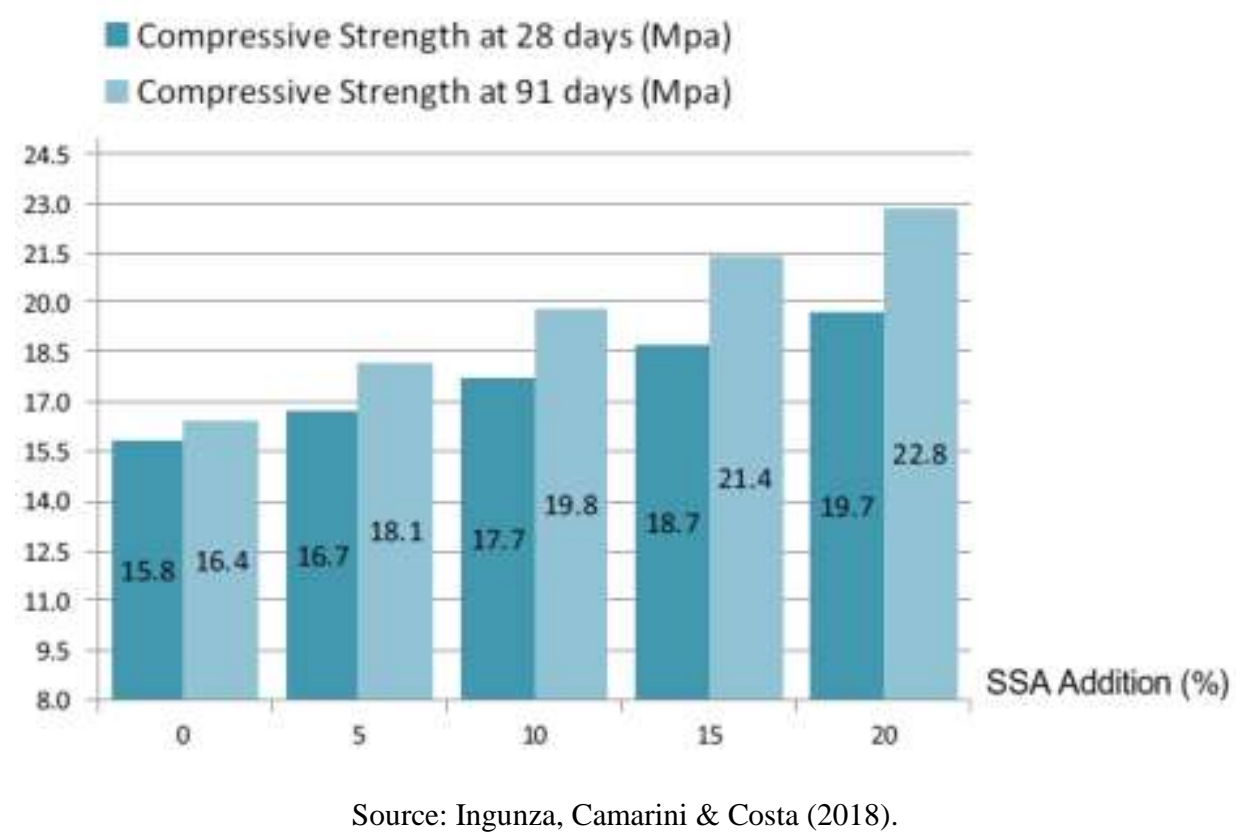


Figure 5 - Flexural strength of mortars at 28 and 91 days with SSA.

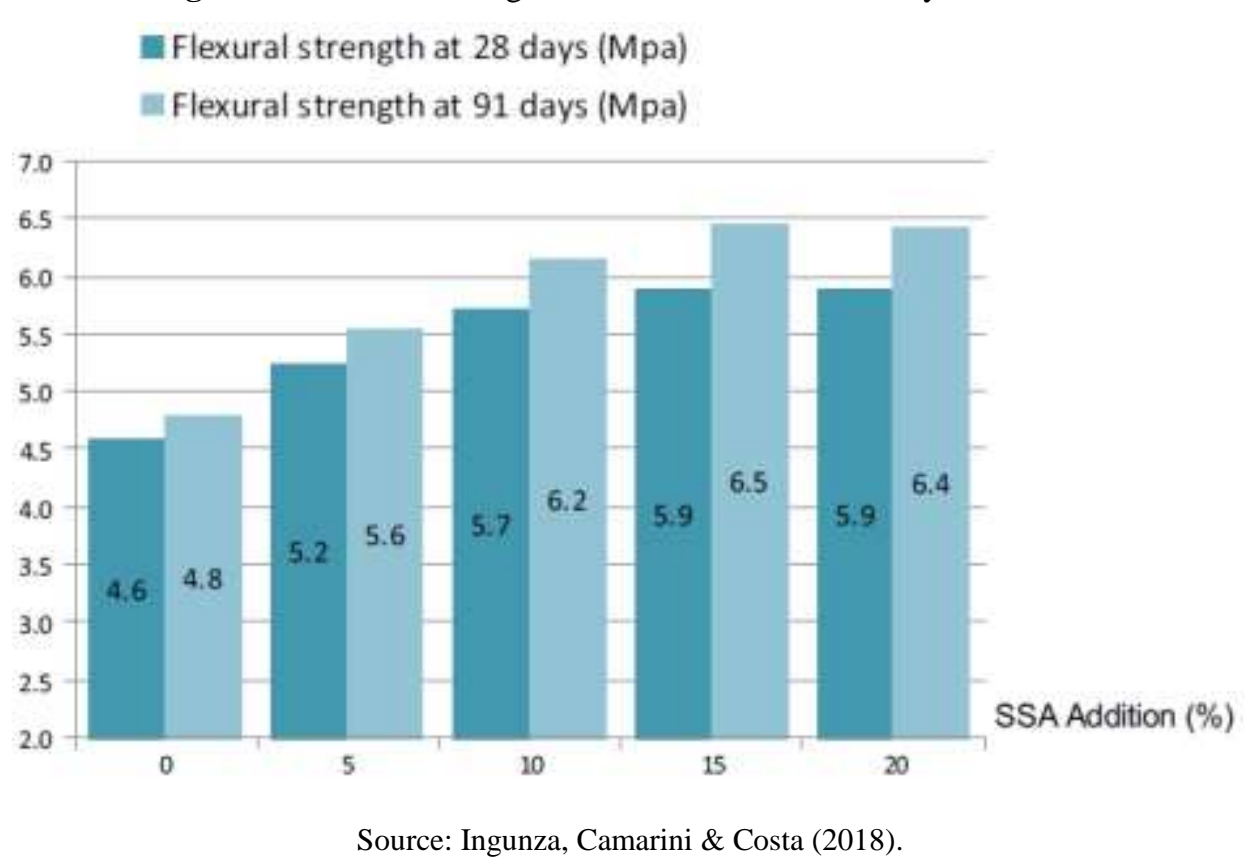

Cunha Oliveira, Chagas, Meira, Carneiro \& Melo Neto (2020), evaluated the use of calcined SSA at $600^{\circ} \mathrm{C}$ and $700^{\circ} \mathrm{C}$, incorporated in coating mortar in percentages of $10 \%, 20 \%$ and $30 \%$, and evaluating the mixtures in terms of flexural strength (Figure 6), and adhesion to the masonry substrate (Table 1). The authors concluded that both temperatures contribute to the SSA becoming reactive enough to be pozzolanic, a factor directly reflected in the increase in the flexural strengths and the adhesion of mortars, with emphasis on $700^{\circ} \mathrm{C}$, which produces more dehydroxylated amorphous structure, that is, more reactive, so the resistance values are higher for the temperature of $700^{\circ} \mathrm{C}$. The percentage of $20 \%$, for both calcination temperatures, was the best for both physical parameters studied, a value in line with the work of Ingunza, Camarini \& Costa (2018), as well as, the values of the tests fit with the pertinent standards for mortars in Brazil.

Figure 6 - Tensile strength at flexure of reference mortar and mortar with calcined slurry at $600^{\circ} \mathrm{C}$ and $700^{\circ} \mathrm{C}$ at $1: 3$ formulation.

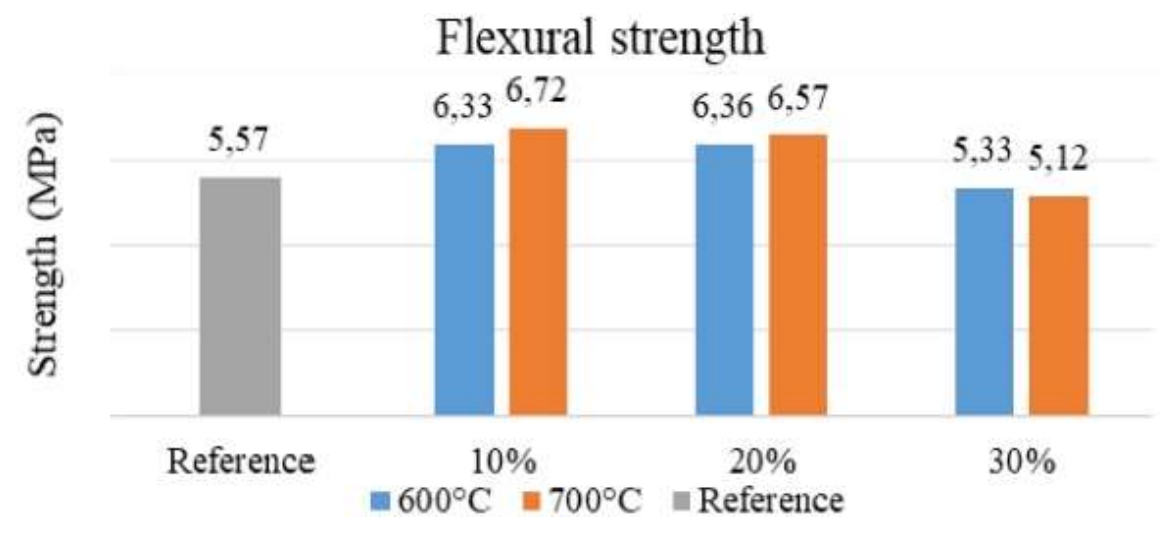

Source: Cunha Oliveira, Chagas, Meira, Carneiro \& Melo Neto (2020). 
Table 1 - Results of the studies concerning the adhesion resistance of the control mortar and of the additives with calcined sludge at $600^{\circ} \mathrm{C}$ and $700^{\circ} \mathrm{C}$, both with a $1: 3$ formulation.

\begin{tabular}{c|c|c}
\hline $\begin{array}{c}\text { Replacement } \\
\text { percentage }\end{array}$ & $600^{\circ} \mathrm{C}$ & $700^{\circ} \mathrm{C}$ \\
\hline Reference & \multicolumn{2}{|c|}{$0,38 \mathrm{MPa}$} \\
\hline $10 \%$ & $0,31 \mathrm{Mpa}$ & $0,32 \mathrm{MPa}$ \\
\hline $20 \%$ & $0,34 \mathrm{MPa}$ & $0,34 \mathrm{MPa}$ \\
\hline $30 \%$ & $0,29 \mathrm{MPa}$ & $0,29 \mathrm{MPa}$ \\
\hline
\end{tabular}

Source: Cunha Oliveira, Chagas, Meira, Carneiro \& Melo Neto (2020).

\subsection{Eco-cement}

An alternative studied for a better destination of the sludge, in addition to its possible use as supplementary cementitious material, is to use it as a raw material in the manufacture of cement. Chen, Ma \& Dai (2010), state that the replacement of limestone in percentages up to $7 \%$ provides higher strengths to cementitious material. From 4 to $10 \%$ substitution, eco-cement showed higher strengths at 3 and 7 days of age compared to the reference composition of cement. At 28 days, the percentage of $7 \%$ is the most favorable to use, reaching strengths around $73 \mathrm{MPa}$.

Lin, Zhou, Li \& Lin (2012), observed the behavior of using dry sewage sludge as an additive in cement properties during the clinker burning process. Additions of 5 and $15 \%$ of dry sludge were added to the raw flour, to then be mix ed and calcined at $1450^{\circ} \mathrm{C}$ for 2 hours, where it was possible to verify that the clinker components of ecological cement with sludge were equivalent to that of simple cement. The results regarding the flexural strength and compression of the hardened ecocement pastes showed that from 5 to $15 \%$ of sludge use there was a balance in the results, not exceeding $2 \%$ for flexion, and $11 \%$ for compression compared to the formulation of reference.

For Yen, Tseng \& Lin (2011), the compressive strengths and microstructural evaluations carried out at 28 days revealed the applicability of eco-cement, involving during the manufacturing process, sewage sludge to replace limestone, the main raw material used in world in obtaining Portland cement. In contents of up to $50 \%$ of limestone substitution, it was possible to verify that the products manufactured with eco-cement produce hydrated phases that better densify the material's microstructure, as the curing is carried out correctly. In view of the mechanical performance of the slurries where they tested eco-cement, the authors noted that the clinker composition with full use of the raw sewage sludge with sludge from a water treatment plant, resistances of over $100 \mathrm{MPa}$ were achieved while the reference formulation ranged from 85 to $90 \mathrm{MPa}$ at 28 days.

Lin \& Lin (2005) also studied the feasibility of eco-cement with raw sewage sludge composing the matrix of Portland cement manufacturing products, and for additions of up to $20 \%$ of the sludge to replace the raw material, superior results were obtained to those obtained with conventional cement. In addition, the production of anhydrous cement compounds stood out with better resistance to compression at 90 days of hydration, reaching more than $100 \mathrm{MPa}$, and compared to the formulation with $0 \%$ sewage sludge, only $90 \mathrm{MPa}$ was obtained.

In studies by Malliou, Katsioti, Georgiadis \& Katsiri (2007), a viable alternative was sought for the final disposal of sewage sludge from urban sewage treatment plants, using it as an additive for the development of cement-based materials, evaluating the traction in the mortar flexion at 28 days of hydration by mapping the products originating in the curing phase of the material through x-ray diffraction and scanning electron microscopy. The authors realized that, through the application of the residue, stabilizing it and solidifying it in the mixture and applying calcium chloride $\left(\mathrm{CaCl}_{2}\right)$ and calcium hydroxide 
$\left(\mathrm{Ca}(\mathrm{OH})_{2}\right)$ with accelerating additives in the hydration process, it improved compressive strength, as this addition has a positive effect. The best results were observed for samples containing $3 \% \mathrm{CaCl}_{2}$ and $2 \% \mathrm{Ca}(\mathrm{OH})_{2}$, through the equivalence in the quantities of cement and added sewage sludge, producing satisfactory properties for an eco-cement that used additives for the immediate advance in the production of hydrated phases of mortar.

Onaka (2000) tested the sludge processing for nine consecutive months in a cement factory, with good results. The process started with the drying of the sludge, transforming it into pellets, but conserving its content of organic matter and energy. These pellets, from 2 to $10 \mathrm{~mm}$ in diameter, were thrown into the oven along with the rest of the cement raw material. The organic matter was used as a complementary source of heat and the inorganic part was part of the clinker. The traces of heavy metals were fixed at levels even more diluted in the cement mass. The monitoring of the gases and the quality control of the product did not indicate any change in relation to the values without the use of the sludge. The results revealed that the incorporation of $2 \%$ of dry sludge as raw material in clinker kilns would allow to consume all the sludge generated in Japan.

Banfill \& Frias (2007), consider the calcined sludge as recycled metakaolin, for producing similar properties when calcined at $700^{\circ} \mathrm{C}$, and for becoming a supplementary cement material when used in mortars. In the same way that metakaolin can be replaced by SSA, as stated by Geraldo (2016), it contributes to a significant reduction in the production of this conventional mineral addition from kaolinite, causing in parallel to reduce the environmental load of the by-product of STPs when correctly disposing of the large volume of sludge generated daily.

\section{Conclusions}

Faced with countless environmental problems experienced, it is necessary that scientists and researchers promote the development regarding the use of materials and components that are easily reincorporated by nature and that reduce pollution. The use of waste in construction processes is a method of inserting the practice of sustainability that provides environmental, economic and social viability, but specifically in construction sites, there are many obstacles in applying technologies that promote any form of execution in civil construction that is differentiated from traditional building systems.

Applying calcined sewage sludge to materials with conventional methodologies, significantly fills several negative factors attributed to incorrect disposal and attitudes that neglect the environmental damage caused, and concludes that there are several ways to assign an increasingly effective destination, in line with the environmental premises and with the quality and performance standards of construction materials, attributing a potential similar or superior to them when the sewage sludge, calcined or in natura, is added to the composition.

Verifying that there is total applicability of sewage sludge, both in its raw dehydrated state and its ashes from the calcination process, it was observed that in several locations, efforts are made to optimize the production process of unconventional materials using the most common techniques applied on a daily basis. Through tests to evaluate the mechanical behavior of materials in specific compositions, it is possible to develop products that have superior properties with regard to the durability and useful life of buildings on a large scale, comparing with the conventional say used worldwide.

It was possible to observe that axial compression strength data and flexural traction data (main properties in the hardened state), obtained by the aforementioned studies, confirmed the potential applicability of the pozzolan obtained at a calcination temperature of 600,700 , and $850^{\circ} \mathrm{C}$ with isotherm time between 2 and 3 hours, producing an amorphous and reactive structure to apply to the materials that carry cement in its composition, as this produces a considerable advance in the properties evaluated in the hardened state.

Eco-cement acts in a similar way to the addition of sludge in mortars, contributing in a unique way compared to the direct insertion in the mixture of sand and cement, besides being fundamentally important to pay attention to reducing the use of raw materials such as limestone and clay, which are fundamental in obtaining Portland cement, but which lead to 
environmental problems such as the production of desertified spaces, erosion and drastic modification of the geographic space, involving the local fauna and flora.

\section{References}

Agopyan, V. (2000). Uso de Resíduos na Indústria da Construção. Palestra no Sustainable Construction into the Next Millennium: Environmentally Friendly and Innovative Cement Based Materials. Proceedings... João Pessoa, PB, Brasil.

Andreoli, C. V., Ferreira, A, C., Bonnet, B. R. P., Lara, A. I., \& Pegorini, E. S. (1998). Produção real e estimativas teóricas de lodo de esgoto no Estado do Paraná. In: I Seminário sobre Gerenciamento de Biossólidos do Mercosul, Curitiba, PR, Brasil, 1998. <https://bit.ly/3h6iuOm>.

Banfill, P., \& Frias, M. (2007). Rheology and conduction calorimetry of cement modified with calcined paper sludge. Cement and Concrete Research, 37 (2), 184-190. https://doi.org/10.1016/j.cemconres.2006.11.013

Brosch, C. D., Alvarinho, S. B., \& Souza, H. R. (1976). Produção de agregado leve a partir do lodo de esgoto. Revista DAE, 104 (354), 53-58. https://bit.ly/3aVhR6w

Chen, H., Ma, X., \& Dai, H. (2010). Reuse of water purification sludge as raw material in cement production. Cement and Concrete Composites, 32 (6), 436439. https://doi.org/10.1016/j.cemconcomp.2010.02.009

Couto, T. A. (2008). Reação álcali-agregado: estudo do fenômeno em rochas silicosas. Dissertação de mestrado, Universidade Federal de Goiás, Goiânia, GO, Brasil.

Cunha Oliveira, J. V. (2020). State of the art of the development of sustainable concrete for applications in conventional structures. Research, Society and Development, 9 (11), 1-19. http://dx.doi.org/10.33448/rsd-v9i11.10272

Cunha Oliveira, J. V., Chagas, L. S. V. B., Meira, F. F. D. A., Carneiro, A. M. P., \& Melo Neto, A. A. (2020). Study of the potential of adhesion to the substrate of masonry and tensile in the flexion in mortars of coating with gray of the sewage sludge. Materials Science Forum, 1012, 256-261. https://doi.org/10.4028/www.scientific.net/MSF.1012.256

Damtoft, J. S., Lukasik, J., Herfort, D., Sorrentino, D., \& Gartner, E. M. (2008). Sustainable development and climate change initiatives. Cement and Concrete Research, 38 (2), 115-127. https://doi.org/10.1016/j.cemconres.2007.09.008

Geraldo, R. H. (2016). Aglomerante álcali-ativado contendo lodo de ETA e cinza de casca de arroz. Dissertação de mestrado, Universidade Estadual de Campinas, Campinas, SP, Brasil.

Geyer, A. L. B. (2001). Contribuição ao estudo da disposição final e aproveitamento da cinza de lodo de estações de tratamento de esgotos sanitários como adição ao concreto. Tese de doutorado, Universidade Federal do Rio Grande do Sul, Porto Alegre, RS, Brasil.

Giffoni, P. O., \& Lange, L. C. (2005). A utilização de borra de fosfato como matéria-prima alternativa para a fabricação de tijolos. Engenharia Sanitária e Ambiental, 10 (2), 128-136. https://dx.doi.org/10.1590/S1413-41522005000200006

Guimarães, J. C. S., Cordeiro, J., \& Vitorino, D. C. F. R. (2018). Use of sewage sludge in agriculture: a scientometric analysis. Research, Society and Development, 7 (9), 1-31. https://doi.org/10.17648/rsd-v7i9.391

Ingunza, M. P. D., Camarini, G., \& Costa, F. M. S. (2018). Performance of mortars with the addition of septic tank sludge ash. Construction and Building Materials, 160, 308-315. https://doi.org/10.1016/j.conbuildmat.2017.11.053

Lei n. 11.445, de 05 de janeiro de 2007 (2007). Estabelece as diretrizes nacionais para o saneamento básico. Diário Oficial da União. Brasília, DF.

Lei n. 12.305, de 02 de agosto de 2010 (2010). Institui a Política Nacional de Resíduos Sólidos. Diário Oficial da União. Brasília, DF.

Lessa, G. T. (2005). Contribuição ao estudo da viabilidade da utilização do lodo de estação de tratamento biológico de esgoto misto na construção civil. Dissertação de mestrado, Universidade Federal do Rio Grande do Sul, Porto Alegre, RS, Brasil.

Lin, K. L., \& Lin, C. Y. (2005). Hydration characteristics of waste sludge ash utilized as raw cement material. Cement and Concrete Research, 35 (10), 19992007. https://doi.org/10.1016/j.cemconres.2005.06.008

Lin, Y., Zhou, S., Li, F., \& Lin, Y. (2012). Utilization of municipal sewage sludge as additives for the production of eco-cement. Journal of Hazardous Materials, 213-214, 457-465. https://doi.org/10.1016/j.jhazmat.2012.02.020

Malliou, O., Katsioti, M., Georgiadis, A., \& Katsiri, A. (2007). Properties of stabilized/solidified admixtures of cement and sewage sludge. Cement and Concrete Composites, 29 (1), 55-61. https://doi.org/10.1016/j.cemconcomp.2006.08.005

Mehta, P. K., \& Monteiro, P. J. (2008). Concreto: Microestrutura, Propriedades e Materiais (2. ed.). New York: McGraw-Hill.

Menezes, R. R., Neves, G. A., \& Ferreira, H. C. (2002). O estado da arte sobre o uso de resíduos como matérias-primas cerâmicas alternativas. Revista Brasileira de Engenharia Agrícola e Ambiental, 6 (2), 303-313. http://dx.doi.org/10.1590/S1415-43662002000200020

Morales, G.; \& Agopyan, V. (1992). Caracterização de agregado leve obtido a partir do lodo de esgoto da cidade de Londrina. Boletim Técnico da Escola Politécnica da USP, São Paulo, EPUSP. https://bit.ly/3teIGJj

Moura, W. A. M. (2000). Utilização de escória de cobre como adição e como agregado miúdo para concreto. Tese de doutorado, Universidade Federal do Rio Grande do Sul, Porto Alegre, RS, Brasil. 
Oliveira, M. A. (2017). Finos de agregados reativos na minimização da reação álcali-agregado. Dissertação de mestrado, Universidade Federal de Ouro Preto, Ouro Preto, MG, Brasil.

Onaka, T. (2000). Sewage can make Portland cement: a new technology for ultimate reuse of sewage sludge. Water Science \& Technology, 41 (8), 93-98. https://doi.org/10.2166/wst.2000.0147

Passeto, W. (2006). Dossiê do Saneamento - Esgoto é vida (4. ed.). Curitiba: cediplac.

Pedroza, M. M., Vieira, G. E. G., Sousa, J. F., Pickler, A. C., Leal, E. R. M., \& Milhomen, C. C. (2010). Produção e tratamento de lodo de esgoto - uma revisão. Revista Liberato, 11 (16), 147-157. https://bit.ly/3efkjXJ

Recena, F. A. P. (2012). Conhecendo argamassa (2. ed.). Porto Alegre: EDIPUCRS.

Santos, A. D. (2003). Estudos das possibilidades de reciclagem dos resíduos de tratamento de esgoto da região metropolitana de São Paulo. Dissertação de mestrado, Universidade de São Paulo, São Paulo, SP, Brasil.

Simoka, B. P. M., Reis, C. Z., \& Boni, H. T. (2016). Utilização de cinzas de lodo agroindustrial na elaboração da argamassa para construção civil. Revista Brasileira de Iniciação Científica, 3 (5), 158-173. https://bit.ly/3eU72Tg

SNIC - Sindicato Nacional da Industria do Cimento. São Paulo, 2012. <https://bit.ly/3uiE8CP>.

Tay, J. H. (1987). Bricks Manufactured from Sludge. Journal of Environmental Engineering, 113 (2), 278-284. https://doi.org/10.1061/(ASCE)07339372(1987)113:2(278)

Viana, M. M. (2013). Obtenção e utilização de produtos de pirólise do lodo de esgoto para adsorção de poluentes em meio aquoso. Tese de doutorado, Universidade de São Paulo, São Paulo, SP, Brasil.

Von Sperling, M., Gonçalves, R. F., \& Luduvice, M. (2001). Remoção da umidade de lodos de esgotos. (Cap. 5, pp. 159-259). Belo Horizonte, Editora UFMG.

Waldemar, C. C. (1992). Avaliação do potencial de utilização do lodo nas estaçães de tratamento de esgotos. Relatório 1. Belém, PA, Brasil.

Yen, C. L., Tseng, D. H., \& Lin, T. T. (2011). Characterization of eco-cement paste produced from waste sludges. Chemosphere, 84 (2), 220-226. https://doi.org/10.1016/j.chemosphere.2011.04.050 